В. Я. Мороз

\title{
ПРОБЛЕМИ УКРАЇНСЬКОГО ЕКСПРЕСИВНОГО ДИСКУРСУ
}

Мороз В. Я. Проблеми українського експресивного дискурсу.

Проаналізовано синтаксичні конструкції експресивного дискурсу. Розглянуто їх структурносинтаксичні особливості і функціональні можливості. Звернено увагу на свосрідність експресивних засобів в утворенні інформаційного поля, в якому знаходять вираження нові форми комунікації.

Ключові слова: експресивний дискурс, бінарне членування, сегментація, парцеляція, ланцюги номінативних речень, інфінітивні структури.

Мороз В. Я. Проблемы украинского экспрессивного дискурса.

Проанализированы синтаксические конструкции экспрессивного дискурса. Рассмотрены их структурно-синтаксические особенности и функциональные возможности. Обращено внимание на важность экспрессивных средств в образовании информационного поля, в котором находять свое выражение новые формы коммуникации.

Ключевые слова: экспрессивный дискурс, бинарное членение, сегментация, парцелляция, цепочки номинативных предложений, инфинитивные структуры.

Moroz V. Ya. Problems of Ukrainian expressive discourse.

The syntactical formations of expressive discourse are analyzed. Their structural-syntactical features and functionality are examined. Attention is drawn to the importance of expressive means in the formation of information field, which find expression new forms of communication.

Key words: expressive discourse, binary segmentation, segmentation, parcelling, the chain of nominative sentences, infinitive structures. 
Проблема дослідження синтаксичної організації експресивного дискурсу на сьогодні $\epsilon$ актуальною і потребує вирішення важливих загальнотеоретичних питань у сфері журналістики, лінгвістики, теорії й історії соціальних комунікацій. В українському мовознавстві цим проблемам присвячені праці Ф.С. Бацевича, А. П. Загнітка, Н.В.Гуйванюк, О.О.Селіванової, В.А.Чабаненка та ін. Теоретичним підгрунтям вивчення цих питань $є$ праці російських учених В. І. Карасика, М. Макарова. В останні роки посилився інтерес дослідників до розгляду мови рекламних текстів. Об'єктом їхньої пильної уваги стали стилістичні способи увиразнення газетного заголовка, структурні особливості слогана як елемента рекламного тексту, синтаксичні конструкції як мовнозображальні засоби експресивного рекламного тексту (О. І. Зелінська, М. М. Кохтєв, Д. Е. Розенталь, П. Л. Коваленко, С. В. Гузенко та ін.).

Мета статті полягає у вивченні синтаксичних засобів експресивного дискурсу в комунікативно-прагматичному i структурно-семантичному аспектах. Актуальність дослідження визначається необхідністю розгляду синтаксичних засобів у досягненні прагматичної мети, потужного їх впливу на читача.

Феномен експресивного дискурсу у сфері лінгвістики, журналістики і соціальних комунікацій виявляється не тільки в тому, щоб «передати адресату ту чи іншу інформацію, а й привернути його увагу до неї, максимально акцентувати іiі i таким чином посилити іiі потужність» [4, c. 238]. Ще В. В. Виноградов, розмірковуючи про експресивні засоби мови, зауважував: «Історія експресивних форм мовлення і експресивних елементів мови взагалі в мовознавстві мало досліджена, шляхи і напрямки їх розвитку в окремих конкретних мовах не з'ясовані» [2, с. 60-87]. Подібне зауваження не втратило своєї актуальності й у наші дні. Починаючи 3 60-х років, у лінгвістичній літературі 3'явився термін «експресивний синтаксис». Спеціальне призначення експресивних синтаксичних побудов, як відзначають дослідники, виявляється не тільки в тому, щоб «передати адресату ту чи іншу інформацію, а й привернути його увагу до неї, максимально акцентувати іiі і таким чином посилити іiі дієвість» [4, с. 238]. Термін «експресивний синтаксис» закріпився за певним колом синтаксичних побудов. До них належать сегментовані, парцельовані побудови, конструкції з суб'єктивно-модальним значенням і сегменти 3 питальною інтонацією, ланцюги номінативних речень, у значній своїй частині інфінітивні побудови, конструкції з лексикосинтаксичним повтором та деякі інші. Серед синтаксичних побудов експресивного дискурсу вирізняються сегментовані та парцельовані утворення. Спільною рисою сегментованих конструкцій $€$ їх виразна двочленність: у першій частині конструкції що-небудь називається, у другій же частині подається характеристика названого [5, с. 14-15]. У сегментованій конструкції з двох речень «Народ! Слово вдарило мені 8 
саме серие, і я схопився, забувши про втому, про спочинок, готовий їхати, мчати, доганяти волю $i$ долю» [3, с. 255] виділяються два сегменти: Народ! - тема; Слово вдарило мені в саме серце, $і$ я схопився, забувши про втому, про спочинок, готовий їхати далі, мчати, доганяти волю і долюрема. Зазначені конструкції вперше виділив О. М. Пєшковський [6, с. 404]. Iз сучасних мовознавців такі побудови досліджували О. С. Попов, I. П. Распопов, К. А. Рогова, Т. Р. Коновалова, Л. Ф. Шильникова, 3. К. Тарланов, Н. П. Харченко, П. С. Дудик, В.І.Кононенко та ін. На сьогодні актуальність вивчення сегментованих конструкцій набуває особливої ваги. Бінарна структура зазначених побудов розглядається дослідниками як на рівні речення, так i на текстовому рівні. Деякі мовознавці пропонують вважати сегментовані конструкції як мовленнєві трансформації мовних синтаксичних моделей речень (наприклад, О. М. Пєшковський, О. С. Попов, Т. Р. Коновалова, Л. С. Майорова та інші), інші - як текстове явище, повне вираження якого знаходимо у складних синтаксичних цілих (Н. С. Валгіна, С. М. Андріянова, О. Ш. Надібаїдзе, Т. М. Ніколаєва, Г. Я. Солганик, Я. І. Рословець, І. Н. Сосинська, Л. М. Лосєва, Л. Ф. Шильникова та інші).

Парцеляція, або розчленування єдиної граматичної структури на частини, є поширеним синтаксичним явищем експресивного дискурсу. До цієї проблеми зверталися Р. О. Рибаков, О. О. Іванчикова, Ю. В. Ванников, К. А. Рогова, О. П. Сковородников, О. Ф. Сфремов. На матеріалі німецької мови подібні побудови вивчали Р. П. Лисиченко, Б. П. Турсунов, В. Г. Адмоні; французької мови - Ж. А. Вітман, Л. С. Сержан, Ю. С. Степанова; англійської - Ж. С. Петрашевська, В. М. Стрельцов, Н. К. Філонова. Парцеляції присвячені кандидатські дисертації Л. І. Ступакової, Ю. Л. Старовойта, Н. М. М'ясищевої та інших. Значна кількість праць свідчить про універсальний характер цього явища. 3 середини 60-х років парцеляція ототожнювалась 3 приєднанням (Н. С. Валгіна, С. А. Реферовська, В Г. Гак ) або розглядалась як складова частина цієї системи (Б. П. Турсунов, В. А. Платонова). У кінці 60-70-х років вчені почали досліджувати структурні особливості парцельованих конструкцій, ї інтонаційні характеристики (Р.П. Лисиченко, В. М. Стрельцов, Л.С. Сержан), експресивність і стилістичні функції (В. А. Платонова, Б. П. Турсунов). У кінці 70-80-х років, а також у 90-ті роки з'являються праці, присвячені вивченню комунікативнопрагматичних функцій парцеляції і приєднання (Л. С. Суровенкова, О. А. Вільчицька). У працях Л. С. Суровенкової і О. А. Вільчицької обгрунтовується думка, що парцеляція і приєднання - різні синтаксичні явища. Мовознавці, які розглядають парцеляцію на формальнограматичному рівні, використовують термін «приєднання». Відповідно до цього розчленовані структури називають приєднувальними конструкціями (ПК). Учені, які розглядають явище розчленування єдиної граматичної 
структури на частини на логіко-семантичному та інтонаційному рівнях (рівень мовленнєвого або актуального членування), використовують термін «парцеляція», а структури, які утворюються в результаті членування, парцельованими конструкціями (Пар. К). Явище парцеляції полягає у виділенні відрізка речення в окрему самостійну частину, яка не пориває семантичного i структурного зв'язку 3 базовою частиною. Парцеляції притаманна множинність членування.

Модальність є однією із малодосліджених лінгвістичних категорій. До цього часу дискусійними залишаються питання про природу й значення засобів створення суб’єктивної модальності в реченні. У сучасному мовознавстві можна виділити два напрямки у трактуванні питання про модальність. Прихильники вузького витлумачення терміна розглядають модальність як категорію, що характеризує ту чи іншу міру реальності / нереальності висловлювання, а прихильники широкого розуміння модальності зараховують до неї виражене знаковими засобами ставлення мовця до дійсності, змісту мовлення, до співбесідника, до самого себе, до форми мовлення, до емоційно-експресивної оцінки повідомлюваного. Виділимо найважливіші засоби, що формують суб'єктивну модальність речення на всіх структурних рівнях мови: 1) на лексичному рівні: значний за обсягом клас займенників, прислівників, коротких форм прикметників, дієслів, часток, вигуків, сполучників та вставних слів 3 модальним відтінком, фразеологічних сполук, синонімів, антонімів, метафор, просторічних слів, діалектизмів, різних пластів лексики, а також лексем 3 послабленими (або взагалі відсутніми) первинними номінативними функціями, які можуть нести в реченні індивідуальні характеристики ставлення мовця до повідомлюваного; 2) на граматичному рівні: синтетичні й аналітичні морфологічні форми повнозначних слів та службових лексем, що мають модальну семантику, синтаксичні засоби вираження модальних значень; 3) на рівні словотвору: система суфіксів оцінки, постфіксів, префіксів та ін.; 4) на морфологічному рівні: форми способу, модальні дієслова, підсилювальні частки, дієприслівникові та дієприкметникові звороти, протиставні сполучники, займенники; 5) на синтаксичному рівні: еліпсис, повтори, паралельні конструкції, інверсія, вставні слова й речення, синтаксичні фразеологізми, уточнення, порівняння, звертання, однорідні та відокремлені другорядні члени речення та цілий ряд інших структур.

Експресивність у реченні досягається за допомогою засобів мови, не пов'язаних 3 певними синтаксичними конструкціями (інтонація, порядок слів) i за допомогою спеціальних експресивних конструкцій. До синтаксичних засобів експресивного дискурсу у значній своїй частині належать інфінітивні речення. Основні синтаксичні ознаки цих побудов: 1) наявність у їх структурі незалежного предикативного інфінітива; 2) присутність при незалежному інфінітиві особливого члена речення, 
вираженого давальним відмінком із значенням непрямого суб'єкта; 3) відношення між дією, названою незалежним предикативним інфінітивом, і непрямим суб'єктом, вираженим давальним відмінком, мають модальний характер.

Інфінітивні речення є предметом дослідження в діахронічному i синхронічному аспектах як у вітчизняному, так i в зарубіжному мовознавстві. Однак при великій увазі багатьох дослідників до цього типу речень, питання їх синтаксичної специфіки лишається ще не з'ясованим. Зокрема, дискусійним є питання про поняття інфінітивного речення, яке багатьма вченими розглядається по-різному. О. О. Шахматов уважає інфінітивними речення будь-якої структури, присудок якої виражений інфінітивом [9, с. 205]. О. М. Пєшковський інфінітивними називає такі речення, у яких присудок виражений непоширеним незалежним інфінітивом [6, с. 381]. Такої ж думки у сучасному мовознавстві дотримуються К. А. Тимофєєв, М. О. Гвоздєв, В. В. Бабайцева та інші. В українському мовознавстві аналогічний погляд висловлюють Н. А. Москаленко, Б. М. Кулик та ін. У розділі «Односкладні речення» П. С. Дудик називає інфінітивними такі односкладні речення, що мають граматично та семантично незалежний від інших членів речення інфінітив у ролі головного члена [7, с. 254]. В. С. Ващенко зазначає, що інфінітив на певних синтаксичних позиціях може утворювати складні факти не тільки структурного типу, а також і стилістичного. Саме такими $є$ так звані інфінітивні речення [1, с. 26]. У сучасному мовознавстві і досі лишається проблемним питання про граматичну сутність інфінітивних речень. Так, Ф. І. Буслаєв, О. О. Шахматов й О. О. Потебня розглядають інфінітивні речення як різновид безособових. Цієї ж думки дотримуються мовознавці Є. М. Галкіна-Федорук, О.Г. Руднєв, Л. А. Булаховський та інші. У сучасному мовознавстві проблемним $є$ питання класифікації інфінітивних речень. Це пояснюється суперечливими поглядами вчених на їх граматичну сутність. Оскільки більшість із названих дослідників розглядають інфінітивні побудови як окремий тип односкладних речень, то виникає проблема їх класифікації. К. О. Тимофєєв привертає увагу до інфінітивних речень і виділяє три їх основні групи: 1) власне інфінітивні речення без частки би; 2)власне інфінітивні речення 3 часткою би; 3) дієслівно-інфінітивні речення з формами дієслова бути. П. С. Дудик здійснює аналіз інфінітивних речень на формально-граматичному рівні і подає подібну їх класифікацію, зокрема виділяє інфінітивні речення 3 часткою би і без неї.

Ланцюги номінативних речень в українській літературній мові посіли значне місце і стали важливим засобом художнього зображення дійсності. Сфера поширення ланцюжків номінативних конструкцій - це переважно художні і публіцистичні тексти. Пояснюється це тим, що специфіка таких побудов, основне їх призначення полягає у створенні 
статичних описів. Такі особливості відтворення думки у тексті характерні саме для художніх творів. Окрім відтворення статичних описів, ланцюги номінативних речень використовуються для зображення динаміки, психічного стану людини тощо. Речення цього типу можуть виконувати в художньому тексті цілий ряд функцій. Функціонування ланцюжків номінативних речень (поєднання 2 і більше подібних одиниць, що мають спільну комунікативну настанову) є одним з яскравих прикладів реалізації мовленнєвої експресії на синтаксичному рівні. На сьогодні дискусійним залишається питання про синтаксичний статус ланцюжків номінативних речень у системі односкладних речень, який мовознавцями визначається по-різному. Питання синтаксичної специфіки таких побудов висвітлюється у працях російських дослідників: М. Лужковської, О. Попова, О. Іванчикової. В українському мовознавстві це питання розглядається у працях П. Дудика, А. Загнітка, В. Чабаненка, I. Сушинської та ін. М. Лужковська у своїх дослідженнях виділила дві групи ланцюжків номінативних речень (однорідні та неоднорідні) на підставі смислових відношень між іменами, які вони утворюють. У працях I. М. Сушинської зазначається, що ланцюжки номінативних речень порушують монолітність складного синтаксичного цілого, що зумовлює актуалізацію змісту, окресленого групою односкладних речень. Вона наголошує, що на відміну від розчленованих побудов, де сегмент i парцелят формально подібні до номінативних речень, не є семантично i структурно автономними, кожне номінативне речення у складі ланцюжка є самостійною предикативною одиницею. При розгляді своєрідної будови ланцюжків вона здійснила лексичний і граматичний їх аналіз та звернула увагу на лексичне наповнення іменників - головних членів, поєднаних у ланцюжки номінативних речень. Таким чином, учені намагаються з'ясувати лінгвістичну суть ланцюгів номінативних речень, визначити їх структурно-синтаксичні та функціональні особливості, місце знаходження в художньому чи публіцистичному тексті, вказати на їхню відмінність від інших засобів експресивного синтаксису. Деякі учені досліджують ланцюжки номінативних речень на функціонально-семантичному рівні i виділяють різні їх типи. Інші розглядають структурно-семантичну типологію ланцюгів номінативних речень та специфіку їх функціонування. Досліджуючи синтаксичні особливості публіцистичних текстів, ми брали до уваги систему мовних засобів, яка сформувалася в результаті відбору і творчого використання синтаксичних явищ української мови не тільки для вираження певного змісту творів, а й для естетичного впливу на читача. Елементи літературно-обробленого синтаксису в художніх текстах найяскравіше виявляються завдяки чіткій, виразній сумірності різних синтаксичних одиниць, конструкцій, стилістичних фігур як особливих побудов оригінальної форми для образного вираження думок і почувань людини. 
Проблема вивчення синтаксичних засобів українського експресивного дискурсу потребує ще наукового й методичного розв'язання, вирішення важливих загальнотеоретичних питань, що на сьогодні набуває особливої ваги й актуальності.

\section{Література}

1. Ващенко В. С. Стилістика речення в українській мові : навчальний посібник з стилістичного синтаксису. - Дніпропетровськ : Дніпр. держ. ун-т, 1968. - 158 с.

2. Виноградов В. В. Итоги обсуждения вопросов стилистики / В. В. Виноградов // Вопросы языкознания, 1955. - №1. - С.60 - 87.

3. Загребельний П. А. Я, Богдан. Сповідь у славі : роман / Павло Архипович Загребельний. - К. : Дніпро, 1984. -285 с.

4. Иванчикова Е. А. О развитии синтаксиса русского языка в советскую эпоху / Е. А. Иванчикова // Развитие синтаксиса современного русского языка. - М. : Наука, 1966. - С. 3 - 22.

5. Иванчикова Е. А. Синтаксические приметы разговорной речи в современной публицистике / Е. А. Иванчикова // Русский язык в национальной школе, 1965. - №4. - С.14 - 15. $511 \mathrm{c}$.

6. Пешковский А. М. Русский синтаксис в научном освещении / А. М. Пешковский. - М., 1956. -

7. Сучасна українська літературна мова. Синтаксис // За заг. ред. академіка I. К. Білодіда. - К. : Наук. думка, 1972. - 322 с.

8. Сушинська I. М. Структурно-функціональні різновиди номінативних речень у сучасній українській мові : автореф. дис. на здобуття наук. ступеня канд. філол. наук. : спеціальність $10.02 .01-$ українська мова / І. М. Сушинська. - Дніпропетровськ, 2000. - 20 с.

9. Шахматов А. А. Синтаксис русского языка / А. А. Шахматов. - Л.: Учпедгиз, 1941. - 620 с. 